\title{
Computer Supported Collaborative Learning and Critical Reflection: A Case Study of Fashion Consumerism
}

\author{
Ada W. W. MA \\ Department of Health and Physical Education, \\ The Hong Kong Institute of Education, Hong Kong SAR, China
}

\author{
ama@ied.edu.hk
}

\begin{abstract}
Computer-supported collaborative learning (CSCL) is believed to be a powerful pedagogical process to equip students with critical reflection to be more sensitive to cultural diversity, stereotypes, and multiple perspectives. The elements of collaborative learning are drawn from research findings and result in a new model to be implemented for learners using Blackboard as avenue for on-line self-reflection and on-going peer critical debate. Participants are students enrolled in a Bachelor of Education program in the field of Home Economics and assigned to group projects. Students are required to undertake a critical analysis of fashion advertisements with reflective ejournals and a reflective paper to question taken-for-granted assumptions. This paper begins with a literature review on critical reflection which demonstrates the problematic nature of defining and researching reflective concepts and techniques, as well as the very wide range of meanings assigned to terms associated with reflection. Next is an outline of the pedagogical design that creates CSCL opportunities and experiences to promote critical reflection in learners. It then highlights students' reflections on how the created peer support system promotes their critical reflective capabilities. Finally, good practices of fostering collaborative reflection are shared that may be adapted in different contexts apart from the teacher education sector.
\end{abstract}

Keywords: computer-supported collaborative learning, critical reflection, social inquiry, lifelong learning

\section{Literature Review}

\section{What is Critical Reflection?}

The development of reflective capabilities is claimed as a goal in many higher education programs, but a review of literature on reflection reveals that the concept is ill-defined and there is little agreement about what reflection is.

Material published as part of this publication, either on-line or in print, is copyrighted by the Informing Science Institute. Permission to make digital or paper copy of part or all of these works for personal or classroom use is granted without fee provided that the copies are not made or distributed for profit or commercial advantage AND that copies 1) bear this notice in full and 2) give the full citation on the first page. It is permissible to abstract these works so long as credit is given. To copy in all other cases or to republish or to post on a server or to redistribute to lists requires specific permission and payment of a fee. Contact 0HPublisher@InformingScience.org to request redistribution permission.
This is mainly due to the fact that the background theory of reflection is complex and wide-ranging, with various generic discipline perspectives presenting multiple interpretations of the processes involved (Henderson, Napan, \& Monteiro, 2004; Moon, 2001).

Reflection in the context of learning is used as a generic term for those intellectual and affective activities in which 
individuals engage in to explore their experiences in order to lead to new understanding and appreciations (Boud \& Walker, 1993, p. 19). Others referred to the common sense view of reflection as:

a form of mental processing - like a form of thinking - that we use to fulfill a purpose or to achieve some anticipated outcome. It is applied to relatively complicated or unstructured ideas for which there is not an obvious solution and is largely based on the further processing of knowledge and understanding an possibly emotions that we already possess. (Moon, 2001, p. 2)

Reflection can be theorised in many ways. Amongst the theoretical approaches to reflection, the work of John Dewey (1933) and Jurgen Habermas (1971) are regarded as the "backbone" of the study of reflection (Moon, 1999). Dewey (1933) is the originator of the concept of reflection as an aspect of learning and education. His work is concerned with the nature of reflection and how it occurs - the skills by which people manipulate knowledge or reprocess it towards a purpose. His definition has been widely used, and is:

Active, persistent and careful consideration of any belief or supposed form of knowledge in the light of the grounds that support it and the further conclusion to which it tends. (p. 9)

Dewey inspired reflection in education to foster pragmatic and instrumental improvement, whereas based on the critical social theory, Habermas inspired reflection in education to foster liberation and emancipation.

Habermas uses reflection to clarify and develop epistemological issues in the sociology of knowledge. He is concerned with the nature of the knowledge that humans have selected to adopt or the nature of knowledge that human beings, by reason of their human condition, have been motivated to generate. In his theory of Cognitive Interests, drawn from ideas of the relationship between knowledge and human interests, Habermas introduces three distinct orientations of knowledge: instrumental (technical knowledge), communicative (practical knowledge), and emancipatory (critical knowledge). Habermas (1971) focuses on the nature of the different processes that underlie the generation of these forms of knowledge, and reflection is one of these processes.

Habermas perceives reflection as a tool used in the development of knowledge constitutive interests - the emancipatory knowledge, where the emancipatory knowledge should contribute to the emancipation of social groups from self-imposed and external constraints, conditions of distorted communication, and environmental constraints. Emancipatory interests rely on the development of knowledge via critical or evaluative modes of thought and enquiry (critical reflection) so as to understand the self, the human condition, and the self in the human context. The acquisition of such knowledge is aimed at producing a transformation in the self, or in the personal, social, or world situation or any combination of these (Moon, 2001).

In Habermas' epistemology, emancipatory knowledge is conceptualised as knowledge that enables human beings to emancipate themselves from forms of domination through critical selfreflection, which takes critical social theory as the psychoanalytical paradigm of critical knowledge. His work is so influential that many sociology educators have further developed and elaborated his understanding on the process of critical reflection using the critical theory approach.

The influence of Habermas' critical theory upon Mezirow's (1991) work is apparent in his following description of reflection as it:

involves the critique of assumptions about the content or process of problem solving...Problem probing involves making a taken-for-granted situation problematic, raising questions regarding its validity. (p. 105) 
Mezirow (1991, p. 108) viewed critical reflection as "becoming aware of why we perceive, think, feel or act as we do." In critical reflection, it is necessary to recognise that many of our actions are governed by a set of beliefs and values that have been almost unconsciously assimilated from a particular environment. Reflection then requires a critical review of presuppositions from conscious and unconscious prior learning and their consequences. Critical reflection is concerned with how consciously the one reflecting takes account of wider historical, cultural, and political values or beliefs in framing and reframing practical problems to which solutions are being sought. Critical reflection should be linked to action so that the individual becomes empowered to act autonomously and is enabled to challenge and change the status quo through the conversation with others to assess and justify their assumptions (Habermas, 1970).

Barnett (1997) provided another example of the application of the knowledge constitutive interests of Habermas to the entire stage of higher education, particularly the emancipatory interests and the associated areas of critical theory. He broadened Habermas' knowledge of constitutive interests by introducing three domains of reflection: the problem at hand (knowledge, skills, approach), the self (including both professional and personal identity), and the social context (broader public, political, and environmental factors). This resulted in a matrix consisting of three domains and four levels of reflection. Level 0 , elementary reflection, referred to evaluations from given criteria. Level 1, technical reflection, referred to solving a problem in a certain context. At level 2, the practical level focused on examination of one's standards of success through the eyes of others. And at level 3, one would search for and question implicit presuppositions at the different levels of critical reflection. Clearly, his understanding on reflection has illuminated its breadth and depth.

This section provides some background to the discussion of reflection in its different contexts. In summary, Dewey considers the process while Habermas considers the place of the process in the acquisition, development, and consideration of knowledge. With the consideration of the motivation that underlies reflection, Habermas' work drives towards the ideals of empowerment and political emancipation (Moon, 1999). The common sense view of reflection often refers to a mental process but with added connotations of purpose or outcome. This study, on the other hand, will adopt Habermas' perspective on emancipatory reflection as it is closely related to its roles in lifelong learning, which will be discussed in the next section. It is important to take this view into account in developing any theoretical context that could have practical implications or evaluations of it in education or practice; this will be discussed in greater depth in the paper.

\section{Critical Reflection and Lifelong Learning}

The development of critical reflective capabilities may help to promote lifelong learning, amongst other things, as one becomes committed to continuous improvement of his or her practice. Lifelong learning is one of the themes of the current educational reform in the HKSAR. The intent of the reforms is to create learning opportunities such that learners are well equipped with generic competencies, such as critical reflection (Education Commission, 2000), to be more sensitive to cultural diversity, stereotypes, and multiple perspectives. Additionally, learners are expected to acquire transferable skills so that they can be responsive to the changing requirements of the workplace and the community.

An individual, as a member of a family and society, will inevitably be involved in confronting issues of inequality and injustice evidenced in our relationships with others, in our families, in the workplace and in society generally. To encourage students to question the social and political forces that provide the context of their work and to question claims of common sense, status quo or "the way things should be", it is important to develop skills to become critical reflective thinkers with the capability to transfer these capabilities to deal with multifaceted problems and reallife issues. Beyer (2001, p. 159) argues that: 
To become an integrated person is not only to understand the social, physical, and political dynamics of the world in which we live and work but to develop the attitudes, forms of consciousness, and commitments that will allow us to take part in shaping and reshaping that world. This emphasis on critique of current realities and on participation in the re-creation of our educational and social worlds is a central part of our understandings of democracy.

Furthermore, Posner (2000) noted that without critical reflective skills the knowledge and skills that teachers gained in their teacher training program might be quickly and easily obliterated. Taking the professional field of Home Economics as an example, Brown $(1993,1995)$ discussed the notion of whether home economics is a community of practice, raised some doubts about this, and then challenged us to critically examine the concepts, beliefs, and values that guide our action (1993, p.193). Therefore, it is important that effective critical reflection is developed among learners so that these attitudes can be examined and challenged in light of current research and practice (Brownlee, Purdie, \& Boulton-Lewis, 2001; Griffin, 2003).

The adoption of Habermas' perspective on emancipatory reflection is justified on the grounds that educators and administrators might learn more about their practice by exploring the issues of power in the classroom, reflecting upon how and by whom knowledge is constructed, looking at whose knowledge is considered valid and reliable, and exploring ways to draw upon indigenous knowledge. Critical reflection is the vehicle for transforming a learner's understanding. It has the effect of a change of knowledge, a change of awareness, and even a change of consciousness. The questioning of basic assumptions and making connections between the students and their context (personal, academic, professional, and so on) are key to integrating and generalising the learning of concepts, courses, program, and disciplines in current and future careers and personal situations. In so doing, we could learn from and affirm the widely diverse voices and experiences of all participants in the teaching and learning process and engage in more vigorous critique, bringing about change in the educational field.

\section{Roles of CSCL in Social Reflection}

Critical reflection is perceived as an essential component in lifelong learning, yet little is known about how it might be promoted. This section will explore the value of Computer Supported Collaborative Learning (CSCL) and social inquiry to foster critical reflective capabilities among learners. Taking the problematic nature of assessing reflection into consideration, an innovative design to facilitate collaborative critical reflection in a CSCL environment is proposed.

\section{Computer-mediated Collaborative Reflective Discourse}

CSCL has become very popular in the 21 st century as computer supported environments have revolutionised the way of learning. Hawkes and Romiszowski (2001) identified several characteristics of computer-mediated communication as the potential avenue for reflective discourse:

(a) the speed, time, and place independence of the medium allows people to engage in discourse, investigate related information, and construct, communicate, and refine ideas in which the thinking aspect of knowledge building is fully maximised;

(b) interaction on multiple conversational topics;

(c) the storage capacity of technology allows users to retrieve segments of a previous discussions, to focus on ongoing dialogue, to challenge the accuracy of documented messages, and to eliminate the pressure and tedious note taking; and

(d) the text orientation tends to heavily omit unnecessary linguistic material to better orient and organise the structure and sequence of decision-making. 
Computer networks offer new vistas for reflection and enable a greater degree of social reflection. Heng and Moor (2003, p. 334) explored the added value of technology to social reflection in light of Habermas' communicative theory, noting that:

The advent of the Internet provides its users with a platform to conduct potentially open discussion, debate and exchange of information, which gives equal opportunity to the participants, and is free from constraints of power relations. It is a kind of communication infrastructure that approaches the requirements of a Habermasian communication, at least potentially.

In the Habermasian scheme of social life, there should be no obstruction to equal communicative exchange between social actors (participants/subjects) so as to allow them to challenge anything they deem important. In the technological sense, the infrastructure provided by the Internet and related networks helps to meet this requirement. Neutrality and transparency have been highlighted as the main strengths in the computer-mediated reflective discourse process (Heng \& Moor, 2003). The neutral discourse procedures, and thus the supporting technologies, should ensure that equal weight is given to all opinions, while not forcing participants into accepting false consensus. Transparency of the discourse process allows participants and third parties to see not only the end results of discussion, but also how these outcomes come to be. The Internet and its associated technology thus provide us with the potential for developmental tools for building a fair playing field for an open forum.

Various studies on socially-mediated reflection in the CSCL environment have illuminated its potential to promote collegial reflection. McMahon's (1996) research on the PBS Mathline project was the first study to address reflection in the context of computer-mediated communication. McMahon studied the flow, frequency, and volume of 393 messages posted over the eight weeks of the course and discovered that $29 \%$ of the participants posted at least one critical reflective message. A study on a group of post registration nursing students utilising reflection in and on action within a CSCL environment indicated that students became more adept at making the links between professional practice and their formal education (Oliver \& Naidu, 1997). A research project conducted by Hawkes (2001) showed that collaboratively produced asynchronous networkbased communication was significantly more reflective than face-to-face discourse between teachers. Some of the CSCL studies (Huynh, 2005; Stahl, 2002) confirmed that group reflection with learners in social contexts was made possible. These studies claimed that the use of technology supported an environment that facilitated shared understanding, enhanced group communication, and promoted equal participation, open communication, and diverse perspectives.

Reflection by nature has a social aspect and is strongly influenced by community activity. Reflective discourse with peers and more experienced others can improve both self and group actions while the process will be enhanced in a CSCL environment.

\section{Promotion of Critical Reflection through E-Reflective Journal Writing and Online Ongoing Peer Debate Utilising Social Inquiry Process}

Despite the fact that extensive efforts have been made to promote social reflection in the CSCL environment recently, research has found that learners do not often engage in critical reflection. This suggests that reflective practices do not take place automatically but require reinforcement with appropriate use of strategies and scaffolding. Literature suggests that reflection is better nurtured under particular conditions (Curtis, 2006; Hatton \& Smith, 1995; Moon, 1999). They are intended to be of practical value and to underpin the tasks and strategies to promote reflection. Taking the work of Jenny Moon (1999) on the conditions for reflection into consideration, initiatives were developed to devise and implement pedagogical strategies that create CSCL opportuni- 
ties and experiences to promote critical reflection in learners. A visual representation of this is presented in Figure 1. With reference to Figure 1, the pedagogical design that is expected to promote critical reflective capabilities in a CSCL environment is detailed in the following section.

\section{Communicative tools}

Asynchronous tools were adopted as the main communication tools to promote social interaction (Mulder, Swaak, \& Kessels, 2002). With the help of a Group Page, each group of students shared their joint documents and conducted intragroup inquiry and reflection. Discussion forums were created and transformed to a reflective learning community that mediated all stages of the challenging process where intergroup ongoing debate, critique, questioning, review, and reflection were carried out. This promoted critical reflection using social support in terms of cognitive diversity and sharing of personal life experiences. The asynchronous nature of discussion allowed ample time and space for reflection while social and teaching presence provided collegial and emotionally supportive environment for successful reflective practice.

\section{Collaborative tasks}

Submission of reflective journals and the writing of an intragroup reflective paper (accompanied by a presentation) following intergroup peer debate were incorporated as collaborative tasks. This was aimed at providing opportunities for the group to undergo argumentative forms of discourse at any point in the process and for the group to engage in dialogue, raise questions, challenge viewpoints, or share similar experiences, so learners could have a chance to review and revisit what they had learned in the process. It is believed that collaborative work with peer input allows a social and psychological analysis of issues as, through critical reflection, the unfolding relations of the group are seen as a microcosm of society, providing the means for understanding wider social and political processes (power, authority, and their relation to gender for example) that are mirrored in the more limited but illuminating life history of the learning group (Reynold, 1998). Strategies employed for this study are justified in the following sections.

\section{Promoting Reflection Using Reflective E-journals}

Journal writing has been espoused as a powerful pedagogical tool to facilitate reflection, promote personal growth, and precipitate change (Hiemstra, 2001; Jensen \& Joy, 2005; Kelly, 2007; Kerka, 2002). As a reflective method, the journal can promote growth, help reconcile the personal with the professional self, and document the writer's growth, development, and transformation. Its helps the writer draw linkages between thoughts, actions, behaviours, beliefs, and values, and offers opportunities to make meaning from experiences by reflecting upon them in writing. It is a useful means to develop nonlinear, divergent thinking, enabling participants to reflect on themselves and share these reflections with a significant other (Mezirow, 1990).

Kelly (2007) suggests that journaling in class might lead to the loss of instructional time needed to teach course material. Technologically-based approaches are asynchronous by nature and they virtually eliminate this potential drawback. E-journals have been found to encourage dialogue on multiple levels - learner to learner, learner to instructor, group, and self; to break up traditional social hierarchies; and to improve reflection allowing the learners to make sense of themselves and the world around them through a cooperative shared venture (King \& LaRocco, 2006; Longhurst \& Sandage, 2004). 
A Model to Promote Critical Reflective Capabilities in a CSCL Environment

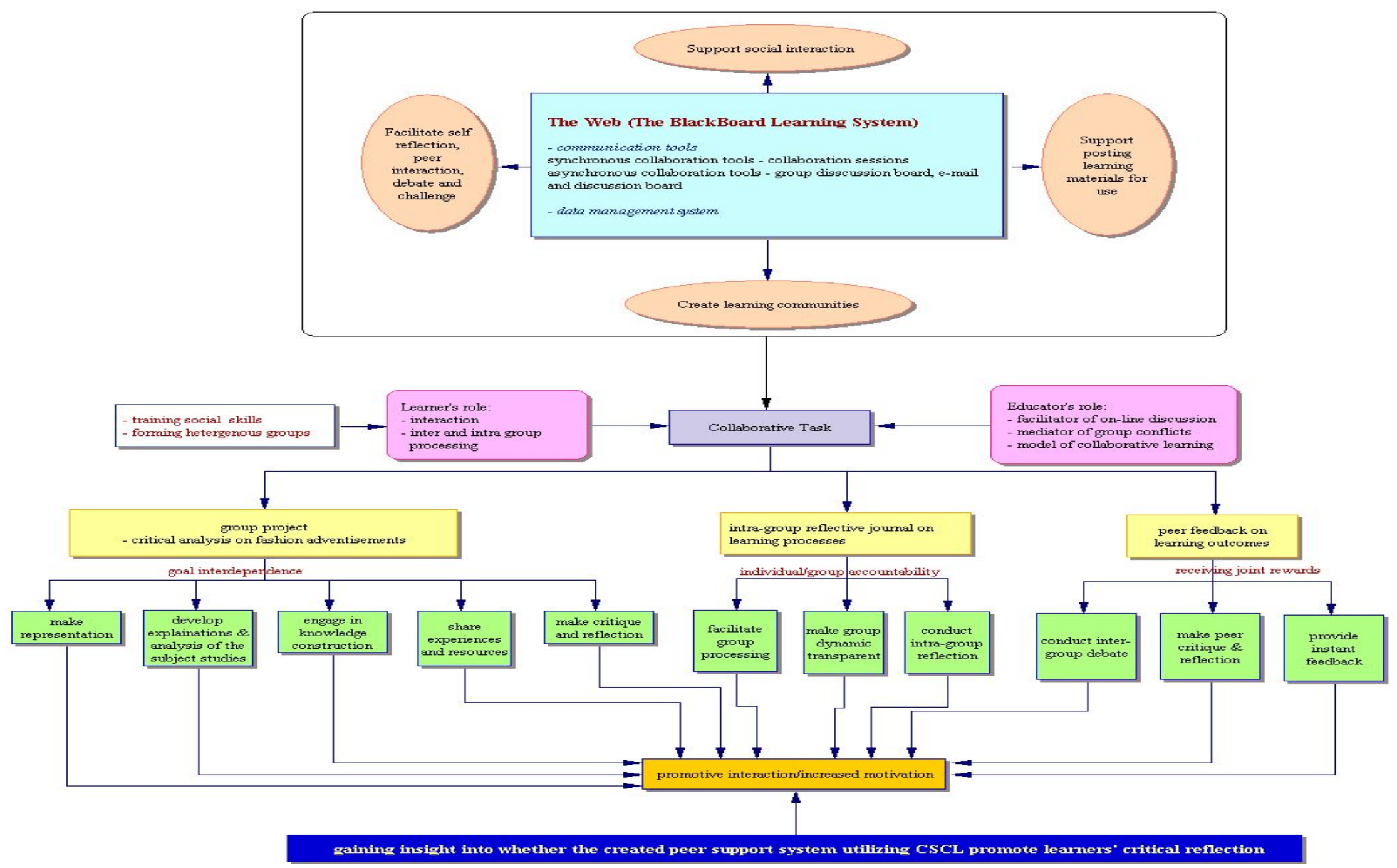

Figure 1. A Model to Promote Critical Reflective Capabilities in a CSCL Environment 


\section{Guiding Critical Reflection Using Social Inquiry Approach}

Hatton and Smith (1995) reviewed 16 research studies investigating the effectiveness of approaches employed to develop a capacity for reflection in student teachers. The common conclusion was that there was little evidence of critical reflection on the part of students, most of whom demonstrated technical and practical reflection. It suggests that careful pedagogical planning is required as learners need to learn strategies, be provided with scaffolding, and practice reflective thinking strategies (Maor, 2003). If reflection is to be guided, the structure of the task provides the best guide for reflection.

As issues of social justice arise in the fashion industry, attempts were made to incorporate social inquiry as a teaching strategy for the module of 'Fashion Consumerism' to assist learners to examine their own assumptions and beliefs as well as to evaluate their biases and prejudicial attitudes through self-reflection and critical debate, resulting in a greater understanding of how values, beliefs, and cultural attitudes influence their perceptions of others and influence their understanding of the world.

Social inquiry is one of the many learner-centred approaches that match the philosophy of contemporary perspectives on learning and teaching. It aims to promote critical reflection with a focus on questioning the taken-for-granted assumptions in society that manifest themselves in the perpetuation of inequity and injustice (Henry, Reynolds, \& Pendergast, 1999). Learners were given a general prompt to be involved in reflective social debate with a predetermined focus by undertaking a critical analysis of a fashion magazine, with the challenges:

- Who is advantaged? Who is disadvantaged?

- What issues of justice and injustice does this raise?

- What unquestioned assumptions about society are evident?

- What is the intention behind including/excluding certain groups?

- Who stands to benefit?

- At what cost and at whose expense do they benefit?

- What can be done to address this situation?

The practice of critical reflection requires a community of peers to uncover commonly held and possibly false assumptions, which is dependent on context and personal experiences. This type of reflection involves social action that includes imagining and exploring alternatives to current assumptions. Those who reflect critically are self-aware and often become more skeptical of the world around them.

\section{Generating Reflection By Means Of Informal Ongoing Peer Debate}

"Hidden" power relationships between facilitator and learners can inhibit reflection. Assessment is a difficult issue when it concerns reflective material as it is the most political of all the educational processes and the area where issues of power are most at stake. If the reflective process is to be assessed then the facilitator of reflection cannot be the critical friend. It is important to ask whether students consciously adopt a style that they think is expected by the facilitator (Shiel \& Jones, 2003) as the anxiety engendered will arise primarily because they are driven by the need to pass the assessment piece and they see their tutors in the powerful role of accreditator. A longitudinal study exploring the experiences of students undergoing a number of assessments of reflection concluded that the process of reflection was better left unassessed (Stewart \& Richardson, 
2000) as students expressed anxiety over the assignment, looked for reassurance when it came to be marked, and were very concerned to do the "right thing".

It is well recognised that assessment strongly influences students' learning, and not assessing reflective activities may suggest to students that reflection is not really valued. Woodward (2002) suggested that the most important aspect of resolving this dilemma was to negotiate with students and staff so that they had some ownership in the process. It is generally accepted that journals themselves should not be subject to grading, but participation or nonparticipation in the reflective process may be evaluated while levels and quality of reflection may be identified to serve as a means to gain insight into the learners' growth and change over time. In this study, the Ereflective journal and the online ongoing peer debate were not assessed with weighting, but formed a prerequisite of the study. Only the reflective paper was marked and a coding scheme used to identify the levels of reflection was solely for teaching/assessment strategies evaluation for improvement, that is, for formative not summative assessment.

\section{Methodology}

\section{Data Collection for Evaluation}

Five groups of 4-6 students were involved in a 5 week project, challenging the taken-for-granted assumptions that had perpetuated injustices and inequalities in fashion advertisements. Students were required to conduct intragroup argumentation online on their selected sets of fashion advertisements using the prompt guides during the first 3 weeks of the project period. The final PowerPoint presentation for inter-group debate was to be submitted in the 4th and 5th weeks. Intragroups were encouraged to have online discussions with their group members during the process and they had to submit reflective journals weekly. The instructor took the role of facilitator during the process and provided overall feedback on learners' participation in the 5th week. Both intragroup and intergroup messages, as well as the weekly reflective journals, were collected and analysed for this project.

In this study, data collected was qualitative in nature. Qualitative information was gathered from students' E-reflective journals, ongoing informal peer debate, and written reflective reports to explore the development of learners' capabilities in critical reflections. Focus group meetings were also conducted with an aim to have in-depth understanding of learners' views on the effectiveness of the created peer support system to promote critical reflective capabilities. Learners were encouraged to give suggestions on improving this practice and all the meetings were tapedrecorded.

The education field places emphasis on equipping learners to be reflective. What is perhaps surprising, however, is that there does not appear to be any widely accepted procedure for determining whether reflective thinking takes place or the assessment of the level and quality of reflective thinking. A search of the literature was unable to find any instances of authors using procedures developed by others, which serves as a proxy for a method for assessing wider acceptance (Bourner, 2003; Hatton \& Smith, 1995; Kember et al., 2000; Moon, 2000; Shiel \& Jones, 2003).

Furthermore, only a few studies addressed the reflective quality of computer-mediated discourse. Of those studies, little description of the reflective processes or outcomes of collaborative reflection was evident (Curtis, 2006; Heng \& Moor, 2003). The lack of computer-mediated reflective processes as a focus of study leaves many questions about the capacity of computer networks to host critical reflective communication. More inquiry is necessary to investigate the potential of the CSCL to promote collegial reflection. The scarcity of readily usable instruments to determine whether students engage in reflective thinking in a CSCL environment and, if so, to what extent, has prompted the study to derive an analytical framework for an analysis of the quality and proc- 
ess of CSCL reflection. Critical social theory is used as a conceptual base, as well as an instrument to study interrelationships with attributes such as subjects, roles, tools, and the CSCL community based on the activity system model.

In light of the suggested length of the paper, discussion on the derivation of a framework for presenting and evaluating evidence and quality of reflective learning, using categories based on Mezirow's (1991) work on reflective thinking and a self-devised analytical tool using reflective processes of the social inquiry model originating from the critical theory of Habermas (1981), has been limited. Nevertheless, Table 1 and 2 outline the content analysis scheme for the study. Participations' reflections on how the created peer support system promotes their critical reflective capabilities will be highlighted in the next section.

Table 1. Content analysis schema for collaborative reflective discourse

\begin{tabular}{|c|c|c|}
\hline $\begin{array}{l}\text { Content analysis } \\
\text { instruments }\end{array}$ & Indicators & $\begin{array}{c}\text { Collaborative } \\
\text { reflective tasks to be } \\
\text { analysed }\end{array}$ \\
\hline \multirow[t]{2}{*}{$\begin{array}{l}\text { Social Inquiry } \\
\text { model originating } \\
\text { from Habermas' } \\
(1981) \text { critical } \\
\text { theory }\end{array}$} & $\begin{array}{l}\text { To capture the progression of reflective thinking } \\
\text { being reflected at different phases of social inter- } \\
\text { action for critical inquiry in the online discourse, } \\
\text { leading to emancipatory actions, it distinguishes } \\
\text { between six phases of social inquiry: } \\
\text { Phase I: Discussion \&initial reaction to practices } \\
\text { \& beliefs } \\
\text { Phase II: Exploration of practices \& beliefs- what } \\
\text { is happening here? What is the impact? } \\
\text { Phase III: Considering issues of ethics and jus- } \\
\text { tice- should it be happening? Who benefits from } \\
\text { the practices? In what ways do they benefit? Who } \\
\text { is disadvantaged? In what ways are they disad- } \\
\text { vantaged? }\end{array}$ & $\begin{array}{l}\text { Computer-supported } \\
\text { collaborative reflective } \\
\text { discourse: } \\
\text { - Intragroup social } \\
\text { inquiry } \\
\text { - Intergroup peer de- } \\
\text { bate }\end{array}$ \\
\hline & $\begin{array}{l}\text { Phase IV: Alternative value positions } \\
\text { Phase V: Adoption and defense of a value posi- } \\
\text { tion } \\
\text { Phase VI: Action planning to redress inequitable } \\
\text { practice }\end{array}$ & $\begin{array}{l}\text { Collaborative reflective } \\
\text { inquiry: } \\
\text { Intragroup reflec- } \\
\text { tive paper }\end{array}$ \\
\hline $\begin{array}{l}\text { Mezirow's reflec- } \\
\text { tion categorisa- } \\
\text { tions based on } \\
\text { Habermas' (1981) } \\
\text { critical theory }\end{array}$ & $\begin{array}{l}\text { To identify levels of collaborative reflection, four } \\
\text { types of reflection are adapted as: } \\
\text { - Non-reflective actions of habitual, thoughtful } \\
\text { and introspection are collapsed and adapted } \\
\text { as Non-reflection } \\
\text { - Content reflection } \\
\text { - Process reflection } \\
\text { - } \quad \text { Premise reflection }\end{array}$ & $\begin{array}{l}\text { Computer supported } \\
\text { collaborative reflection } \\
\text { - Intragroup reflec- } \\
\quad \text { tive journal }\end{array}$ \\
\hline
\end{tabular}


Table 2. Content analysis scheme for the study

\begin{tabular}{|c|c|c|}
\hline Instruments adopted & Aspect to be evaluated & Unit of analysis \\
\hline & $\begin{array}{l}\text { Level and intensity of partici- } \\
\text { pation }\end{array}$ & Usage statistics \\
\hline Henri (participative presence) (1992) & Nature of interaction & Message unit \\
\hline $\begin{array}{l}\text { Mezirow's (1991) categorisations on } \\
\text { reflection ) } \\
\text { Self-devised instrument with adoption } \\
\text { of the social inquiry model originat- } \\
\text { ing from Habermas's (1981) critical } \\
\text { theory }\end{array}$ & $\begin{array}{l}\text { Reflective presence- } \\
\text { a. levels of reflection } \\
\text { b. process of social reflection; } \\
\text { social co-creation of new } \\
\text { knowledge for transformative } \\
\text { actions }\end{array}$ & Message unit \\
\hline $\begin{array}{l}\text { Rourke, Anderson, Garrison, \& } \\
\text { Archer (1999) }\end{array}$ & Social presence & Message unit \\
\hline $\begin{array}{l}\text { Anderson, Rourke, Garrison, \& } \\
\text { Archer (2001) }\end{array}$ & Teaching presence & Message unit \\
\hline
\end{tabular}

\section{Data Analysis and Findings}

\section{Did the Created Peer Support System Within The CSCL Environment Foster Critical Reflective Capabilities? - Feedback Elicited From Focus Group Meetings}

It was evident that student perceptions through intra-group reflection taken from the weekly reflective journals was a useful practice to promote their reflective capabilities, self-monitoring skills, and openness to feedback among the other learners.

When I knew I had to submit reflective journals, I thought it was just a formality and did not take the work seriously, feeling that it was useless to my study. But when I started to prepare it on a weekly basis and after four weeks I looked back my work, I realized I had improved a lot! $(G A-S 3)$

Usually we made reflections on our learning after we had submitted our assignment. Weekly submission of reflective journals made us to conduct on-going reflections during the learning process which allowed us to come up with a course of action for improvement. (GB-S2)

My capacity to make reflection was stronger. After I had read others' comments, I would rethink them again and make judgments. If I did not agree with them, I would search for more information to support my views. (GC-S3)

The shift of the peer assessment design to informal ongoing feedback about peer performance resulted in significant improvement in student learning. Most students indicated that the ongoing peer critiques conducted in the CSCL environment did foster critical inquiry skills. The following comments illustrate this:

Our critical analysis (intra-group discussion) on advertisements had been promoted. We no longer believed in what the advertisements had tried to portray now. We challenged whether the advertisements had carried any hidden messages that we had taken for granted in the past. (GC-S1)

We might be subjective in many ways, yet this mode of interaction provided us a chance to reflect on how we made judgments to form our perspectives. It also fostered our openness to 
peers' feedbacks as well. (GA-S1)

(Inter-group peer critiques) helped us to identify our bias and deficiencies as peers commented at our work from different perspectives. (GA-S2)

After several rounds of discussion (inter-group peer critiques), our critical thinking skills had been promoted as the findings were come up with thorough thinking. (GB-S2)

One's thought was highly related to one's background and characteristics. Without the interaction from online discussion, we might perceive the world with bias. (GC-S2)

Furthermore, through instant online peer critiques, the students were challenged with assumptions from multiple perspectives, were exposed to a variety of social interactions, and were subject to ongoing support from the facilitator in the learning process as well as experience in trust building and strengthening team spirit. This was highlighted among the groups through the learners' critical reflection:

Our discussion and reflective skills had been improved as I could obtain more instant feedbacks form classmates online. (GC-S1)

I had chances to make a lot of good friends who gave me a lot of valuable suggestions in online discussion which had broadened my perception of the world. Our mutual trust had been built and became more open to others' comments. (GE-S1)

Without this experience of online critical inquiry, one might believe that learners were not able to manage such mode of learning. I had tried it out in my secondary teaching; it worked well with students as they remarked that they could think more deeply with peers' critiques. (GA-S2)

Our lecturer had been following us very closely and her supportive feedbacks highly motivated us to pay more effort on discussion the next time. Her encouraging comments also helped us to build up our confidence on the tasks. (GB-S3)

Student comments indicated that they were largely positive about the reflective process. CSCL tasks require students to critique their peers and to conduct peer debates in which learners are engaged with useful and constructive feedback and act upon it to improve their learning and their perception of the world. Students are also involved in assessing peers and evaluating themselves so as to take responsibility for self-monitoring and making judgments about aspects of their own learning. Fostering of such critical reflective skills is important in their future working lives as they will need to ensure that their work meets the qualities required by their profession, their employers, or their clients.

\section{Discussion and Conclusion}

\section{Good Practices to Enhance Collaborative Reflection}

Learners' views in the focus group meetings suggest that the process of reflection is actively facilitated through interactive journal writings and peer debate in a CSCL environment with a social inquiry approach. Learning to reflect was a difficult process for students and entailed the use of skills that few students possessed at the beginning of their learning. This confirmed the contention that learner-as-reflective-practitioner will not just happen simply because it is a good idea. Unless critical reflection is planned as part of the process or becomes an objective of a task itself, reflective activities will be sporadic at best. Insights gained in this study on promoting critical reflective capabilities among student-teachers in the CSCL environment will be shared. The practices provide a useful starting point for exploring what might be adapted in different situations in 
order to facilitate effective teaching and learning experiences, ultimately leading to the development of lifelong learning capabilities such as critical reflection in students.

- Discourage the facilitator from developing the position as a power base or structure. The facilitator should adopt a noninterventionist approach as far as possible. It requires finesse for the facilitator to intervene promptly to help resolve peer conflicts in argumentations or confrontations that might adversely affect the supportive interpersonal relationships and the subsequent reflective inquiry process.

- Assessment design for reflective practices should enable students to be really free to reflect and express their own views. To eliminate the possible hidden power relationships between facilitator and learners that might inhibit reflection, the best way to assess collaborative reflective tasks is not with weightings, but from a prerequisite for the completion of the module.

- Reflection is developmental in nature and selection of instructional methods must reflect this understanding. It is revealed that the social inquiry approach with guided processes does facilitate the development of critical reflective thinking. The question (task) guidelines help to prompt/guide the students to have more profound reflection phase by phase. In this study, the nature of the guiding questions influenced the level of response from the learners. The questions created to trigger personal stories and to target issues from a moral and ethical point of view were successful as was revealed in the critical reflection. This suggests that the activities that cause the reflection must be properly integrated into the module to maximise their effect.

- CSCL is highly recommended as a pedagogical strategy to foster critical reflective capabilities. Reflection by nature has a social aspect and is strongly influenced by the community activity. Reflective discourse with peers and more experienced others can improve both self and group actions. This process will be enhanced in a CSCL environment.

- Critical reflective capabilities can be fostered with appropriate pedagogical design. However, learners may learn or benefit from collaborative reflective activities, some of which may not be demonstrable in the short term. In order to foster learners with generic skills such as critical reflection, what is needed is time and opportunity for development so that the required essential meta-cognitive skills can be promoted and retained. It suggests that such reflective practice has to be promoted in various courses that can identify evidence of a developmental process over time, regardless of the start or end point. It is important that being reflective should be considered as an outcome of a total learning effort that is richly addressed in variety of ways throughout the university experience - including a campus-wide initiative to promote reflective learning.

- To be a lifelong learner, educators should work at changing their own practices, so as not to have educational institutions perpetuate an environment that may inadvertently promote unjust power and inappropriate gender relationships. Educators should examine their beliefs about teaching and learning and construct their knowledge in a supportive environment encouraging risk taking and reflection. Reflective practice such as this is necessary for us to meet the increasingly complex roles we are asked to play. It enables educators to examine the issues of ethics, morals, and justice in education, opening up discourse about the role of education in a democratic society.

Good practice presented above is adaptable and lends itself to modification to suit particular contexts to support student-centred learning and contribute to desirable learning outcomes, preparing them to be critical reflective learners. The practices are not finite. They are generated out of a particular context in which this research study is undertaken. These practices cannot be directly applied to a new situation without modifications. However, these practices will stimulate thought, 
be adapted in small or major ways, and lead to better, more effective practices for academics and better learning experiences and opportunities for students.

\section{References}

Anderson, T., Rourke, L., Garrison, D. R., \& Archer, W. (2001). Assessing teaching presence in a computer conference context. Journal of Asynchronous Learning Networks, 5(2). 1-17. Retrieved 18 May 2007 from http://www.aln.org/publications/jaln/v5n2/pdf/v5n2 anderson.pdf

Barnett, R. (1997). Higher education: A critical business. London: SRHE and Open University Press.

Beyer, L. E. (2001). The value of critical perspectives in teacher education. Journal of Teacher Education, 52(2), 151-163.

Boud, D., \& Walker, D. (1993). Barriers to reflection on experience. In D. Boud, R. Cohen \& D. Walker (Eds.), Using experience for learning, (p.73-86). Bristol: Open University Press.

Bourner, T. (2003). Assessing reflective learning. Education and Training, 45(5), 267-272. Boston: MCB UP Limited.

Brown, M. (1993). Philosophical studies of home economics in the United States: Basic ideas by which home economists understand themselves. East Lansing, MI: Michigan State University Press.

Brown, M. (1995). The concept of community. Kappa Omicron Nu FORUM, 8(2), 7-20. Retrieved March 6, 2008 from http://www.kon.org/archives/forum/forum_8_2.pdf

Brownlee, J., Purdie, N. \& Boulton-Lewis, G. (2001). Changing epistemological beliefs in pre-service teacher education. Teaching in Higher Education, 6(2), 247-268.

Curtis, J. N. (2006). Using online discussion forums to promote critical reflection among pre and in-service HIV/AIS educators and service providers. International Electronic Journal of Health Education, 9 , 166-179.

Dewey, J. (1933). How we think: A restatement of the relation of reflective thinking to the educative process. Boston: D. C. Heath.

Education Commission. (2000). Learning for life, learning through life - Reform proposals for the education system in Hong Kong. Hong Kong: Government Printer.

Griffin, J. D. (2003). Technology in the teaching of neuroscience: Enhanced student learning. Advances in Physiology Education, 27, 146-155.

Habermas, J. (1970). Towards a theory of communicative competence. Inquiry, 13(4), 360-376.

Habermas, J. (1971). Knowledge and human interests. Boston: Beacon Press.

Habermas, J. (1981). The theory of communicative action: Reason and the rationalisation of society. London: Heinemann Educational Books.

Hatton, N., \& Smith, D. (1995). Reflection in teacher education: Towards definition and implementation. Journal of Teacher Education, 41(4), 23-32.

Hawkes, M. (2001). Variables of interest in exploring the reflective outcomes of networked-based communication. Journal of Research on Computing in Education, 33(3), 44-56.

Hawkes, M., \& Romiszowski, A. (2001). Examining the reflective outcomes of asynchronous computermediated communication on in-service teacher development. Journal of Technology and Teacher Education, 9(2), 285-308.

Henderson, K., Napan, K., \& Monteiro, S. (2004). Encouraging reflective learning: An online challenge. In R. Atkinson, C. McBeath, D. Jonas-Dwyer \& R. Philips (Eds.), Beyond the comfort zone: Proceedings of the $21^{\text {st }}$ ASCILITE Conference, (p.357-364). Perth, Australia.

Heng, M. S. H. \& Moor, A. D. (2003). From Habermas's communicative theory to practice on the internet. Information System Journal, 13(4), 331-352. 
Henri, F. (1992). Computer conferencing and content analysis. In A. R. Kaye (Ed.), Collaborative learning through computer conferencing: The Najadan Papers (p. 117-136). London: Springer-Verlag.

Henry, M. I., Reynolds, J., \& Pendergast, D. (1999). Social inquiry: An approach to learning and teaching in Home Economics. Australia: Home Economics Institute of Australia Inc.

Hiemstra, R. (2001). Uses and benefits of journal writing. New Directions for Adult and Continuing Education, 90, 19-26.

Huynh. M. (2005). Viewing e-learning productivity from the perspective of Habermas' cognitive interests theory. Journal of Electronic Commerce in Organizations, 3(2), 33-45.

Jensen, S. K., \& Joy, C. (2005). Exploring a model to evaluate levels of reflection in baccalaureate nursing students' journals. Journal of Nursing Education, 44(3), 139-142.

Kelly, M. (2007). Journals in the Classroom. Retrieved 6 June 2007 from http://712educators.about.com/cs/writingresources/a/journals.htm.

Kember, D., Leung, D., Jones, A., Loke, A., Mckay, J., Sinclair, K., et al. (2000). Development of a questionnaire to measure the level of reflective thinking. Assessment \& Evaluation in Higher Education, 25(4), 381-395.

Kerka, S. (2002). Journal writing as an adult learning tool. Practice Application Brief No. 22 ACVE. Retrieved 6 June 2007 from: The Clearing House on Adult, Career, and Vocational Education (ACVE) Web site: http://www.cete.org/acve/docgen.asp?tbl=pab\&ID-112.

King, F. B., \& LaRocco, D. J. (2006). E-Journaling: A strategy to support student reflection and understanding. Current Issues in Education, 9(4). Available On-line: http://cie.ed.asu.edu/volume9/number4/.

Longhurst, J., \& Sandage, S. A. (2004). Appropriate technology and journal writing: Structured dialogues that enhance learning. College Education, 52(2), 69-75.

Maor, D. (2003). The teacher's role in developing interactions and reflections in an online learning community. Education Media International, 40(1/2), 127-137.

McMahon, T. A. (1996). From isolation to interaction? Computer-mediated communications and teacher professional development. Unpublished doctoral dissertation, Indiana University, Bloomington, IN. Retrieved 30 August 2003 from www.questia.com/PM.qst? $a=0 \& s e=g g l s c \& d=5002415132$

Mezirow, J. (1990). How critical reflection triggers transformative learning. In J. Mexirow \& Associates (Eds.), Fostering critical reflection in adulthood: A guide to transformative and emancipatory learning (pp. 1-20). San Francisco, CA: Jossey-Bass.

Mezirow, J. (1991). Transformative dimensions of adult learning. San Francisco, CA: Jossey-Bass.

Moon, J. (1999). Learning journals: A handbook for academics, students and professional development. London: Kogan Page.

Moon, J. (2000). Reflection in learning \& professional development: Theory and practice. London: Kogan Page.

Moon, J. (2001). PDP working paper 4: Reflection in higher education learning. UK: LTSN Generic Centre.

Mulder, I., Swaak, J., \& Kessels, J. (2002). Assessing group learning and shared understanding in technology-mediated interaction. Educational Technology \& Society, 5(1), 35-47.

Oliver, M., \& Naidu, S. (1997). Computer supported collaborative reflection in and out action in nursing education. Queensland: University of Southern Queensland.

Posner, G. (2000). Field experience: A guide to reflective teaching. New York: Longman.

Reynold, M. (1998). Reflection and critical reflection in management learning. Management Learning, 29(2), 183-200. 
Rourke, L., Anderson, T., Garrison, D. R., \& Archer, W. (1999). Assessing social presence in asynchronous text-based computer conferencing. Journal of Distance Education, 14(3), 51-70.

Shiel, C., \& Jones, D. (2003). Reflective learning and assessment: A systematic study of reflective learning as evidenced in students' learning journals. HEAC, p. 1-32. Available online at http://eprints.bournemouth.ac.uk/1390/1/Shiel Output 1.pdf

Stahl, G. (2002). Contributions to a theoretical framework for CSCL. Proceedings of the Computer Support for Collaborative Learning (CSCL) 2002 Conference. Retrieved 5 November 2003 from: http://newmedia.colorado.edu/cscl/81.pdf

Stewart, S., \& Richardson, B. (2000). Reflection and its place in the curriculum on an undergraduate course: should it be assessed? Assessment \& Evaluation in Higher Education, 25(4), 369 - 380.

Woodward, H. (2002). The reflection jigsaw. In P. Schwartz \& G. Webb (Eds.), Assessment: Case studies, experience and practice from higher education (p. 32-40). London: Kogan Page.

\section{Biography}

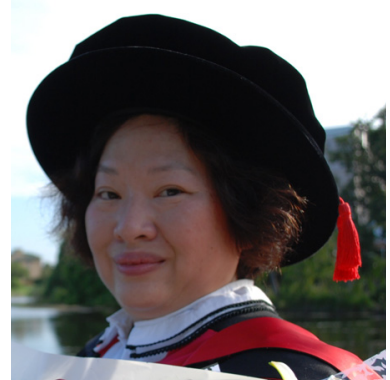

Dr. Ada Ma is the assistant professor of Technology and Living Division of the Department of Health and Physical Education, at the Hong Kong Institute of Education. She is currently teaching Technology and Living with a focus on textiles for both full-time and part-time Bachelor and Master Degree programmes. She is interested in various research areas such as computer-supported collaborative learning, textiles education, curriculum innovations, assessment, lifelong learning and gender issues. She has participated actively in various academic activities ranging from publication of conference proceedings, referred journal papers and book chapters to being a research investigator of internal and external funded projects, as well as a reviewer of various international referred journals. 